Marzena Karpińska

ORCID: 0000-0002-7578-2233

Uniwersytet Wrocławski

https://doi.org/10.19195/1733-5779.32.13

\title{
Rola funduszy europejskich w procesie zarządzania projektami
}

\author{
JEL Classification: M10
}

Słowa kluczowe: POIR, innowacyjność, fundusze europejskie, $\mathrm{B}+\mathrm{R}$

Keywords: POIR, innovation, European funds, R\&D

Abstrakt: Celem niniejszej pracy jest przedstawienie zagadnień związanych z rolą funduszy europejskich w procesie zarządzania projektami. We współczesnej gospodarce coraz większe znaczenie zaczynają odgrywać innowacyjne technologie, ponieważ innowacyjność staje się istotnym instrumentem konkurowania ${ }^{1}$ oraz ważną siłą napędową prawidłowo funkcjonujących gospodarek $^{2}$. Gospodarka wymusza nieustanne poszukiwania nowych rozwiązań w wielu dziedzinach życia ${ }^{3}$, dlatego tak ważne stały się środki unijne.

\section{The role of the European fund in the project management process}

Abstract: The purpose of this work is to present issues related to the role of European funds in the project management process. Innovative technologies are beginning to play an increasingly important role in the modern economy, as innovation is becoming an important instrument of competition and an important driving force of properly functioning economies. The economy forces the constant search for new solutions in many areas of life, which is why EU funds have become so crucial.

1 A. Kabalska, Innowacje w kreowaniu i modyfikowaniu modeli biznesowych, [w:] Wybrane koncepcje zarzadzania w organizacjach, red. M. Smolarek, Sosnowiec 2016, s. 14-15.

2 R. Klóska, Innwacyjność polskiej gospodarki, „Studia Zarządzania i Finansów Wyższej Szkoły Bankowej w Poznaniu" 2015, nr 9, s. 25-27.

3 A. Pomykalski, Zarzadzanie innowacjami. Globalizacja, konkurencja, technologia informacyjna, Warszawa-Łódź 2001, s. 25. 


\section{Wprowadzenie}

Najważniejszą rolę w rozwoju gospodarczym oraz społecznym każdego kraju odgrywają przedsiębiorstwa - dlatego też wsparcie przedsiębiorczości to jeden z głównych obszarów polityki UE. Mimo że przepisy obowiązujące w Unii Europejskiej sprzyjają sprawnemu funkcjonowaniu przedsiębiorstw na rynku, w dalszym ciągu inicjuje się działania, które mają ulepszyć to prawo 4 .

Cele, które zawarto w Traktacie o Unii Europejskiej, sformułowane zostały w sposób następujący:

- popieranie postępu gospodarczego oraz społecznego, a także wysokiego poziomu zatrudnienia i doprowadzenie do zrównoważonego, a także trwałego rozwoju, zwłaszcza poprzez utworzenie przestrzeni bez granic wewnętrznych, umocnienie gospodarczej i społecznej spójności, a także ustanowienie unii gospodarczej i walutowej, obejmującej docelowo jedną walutę, zgodnie z postanowieniami niniejszego Traktatu;

— potwierdzanie swej tożsamości na arenie międzynarodowej, zwłaszcza poprzez realizowanie wspólnej polityki zagranicznej i bezpieczeństwa, w tym stopniowe określanie wspólnej polityki obronnej, która zgodnie z artykułem 17 mogłaby prowadzić do wspólnej obrony;

- umacnianie ochrony praw i interesów obywateli jej Państw Członkowskich poprzez ustanowienie obywatelstwa Unii;

- utrzymanie i rozwijanie Unii jako przestrzeni wolności, bezpieczeństwa i sprawiedliwości, w której zagwarantowana jest swoboda przepływu osób, w powiązaniu z właściwymi środkami w odniesieniu do kontroli granic zewnętrznych, azylu, imigracji oraz zapobieganie i zwalczanie przestępczości;

— pełne zachowanie dorobku wspólnotowego i jego rozwój, z uwzględnieniem zakresu, w jakim polityki i formy współpracy, ustanowione niniejszym Traktatem, wymagają zrewidowania w celu zapewnienia skuteczności mechanizmów i instytucji Wspólnoty ${ }^{5}$.

Przy wykorzystaniu instrumentów, jakimi są fundusze strukturalne oraz fundusze spójności, podejmowane są próby osiągania powyższych celów. Fundusze strukturalne określane są jako ,instrumenty polityki strukturalnej Unii Europejskiej, których zadaniem jest wspieranie restrukturyzacji i modernizacji gospodarek krajów UE"6. Celem nadrzędnym jest zwiększenie poziomu spójności ekonomicznej i społecznej w ramach całej Wspólnoty. Fundusze strukturalne przekazywane są do tych dziedzin gospodarki i tych regionów, które bez zewnętrznego wsparcia finansowego nie są w stanie funkcjonować ani osiągnąc średniego poziomu ekonomicznego w UE.

Przedstawione powyżej cele bardzo dokładnie pokazują, że w polityce UE istotne znaczenie mają działania na rzecz rozwoju przedsiębiorstw, wspierania procesu tworzenia miejsc pracy oraz zwiększenia konkurencyjności przedsiębiorstw,

4 W. Leoński, Wplyw Unii Europejskiej na rozwój polskich przedsiębiorstw, „Handel Wewnętrzny" 2015, nr 3, s. 121.

5 Traktat o Unii Europejskiej, 7.02.1992, Maastricht, https://eur-lex.europa.eu/eli/treaty/teu_ 2012/oj (dostęp: 10.05.2019).

${ }^{6}$ Rozporządzenie Rady nr 1260 z dnia 21 czerwca 1999 roku, https://op.europa.eu/pl/publication-detail/-/publication/0495cad8-bda6-4b4f-852c-ce3dd3022392/language-pl (dostęp: 10.05.2019). 
a także polepszenie ramowych warunków konkurencji ${ }^{7}$. Unia Europejska bardzo zabiega o ograniczenie bądź też całkowitą likwidację różnego typu barier, które utrudniają zakładanie i prowadzenie działalności gospodarczej. Do barier wyeliminowanych lub znacząco ograniczonych w związku z przystąpieniem Polski do UE zalicza się bariery techniczne, fizyczne i fiskalne ${ }^{8}$.

\section{Istota funduszy europejskich}

Istotnym wymiarem rozwoju UE są przedsięwzięcia realizowane z wykorzystaniem funduszy europejskich, zwłaszcza w ramach polityki spójności. Na lata 2014-2020 przeznaczono budżet w wysokości prawie 352 miliardów euro; dodatkowo należy zauważyć, że wieloletnie ramy finansowe 2007-2013 przyjęte były w kwocie 347 miliardów euro ${ }^{9}$. Lata realizacji licznych wysokobudżetowych projektów nie wygenerowały oczekiwanych efektów. Początek XXI wieku przyniósł wiele prób ratowania polityki spójności, jednak nadal podejmowane działania nie przynosiły pożądanych efektów ${ }^{10}$. Okazało się, że mimo obszernego spektrum beneficjentów polityki spójności wymiar korzyści był bardzo zróżnicowany.

Wiele zrealizowanych dotychczas projektów z powodzeniem zostało wdrożonych przez przedsiębiorstwa; zdarzało się jednak, że były to przedsięwzięcia o charakterze pozornym. Niestety, dochodziło również do tego, że gromadzenie dotacji dla wielu przedsiębiorców okazało się być podstawowym celem funkcjonowania ich podmiotów w ramach stałego lub dodatkowego wynagrodzenia. Przedsiębiorcy, wykorzystując okazję, decydowali się na realizację działań, które wpisywały się w ściśle określoną dotację. Było tym bardziej korzystne, im dłuższy okazywał się okres realizacji projektu.

System wspierania rozwoju przedsiębiorstw tworzą różnego typu instrumenty. Do najczęściej wskazywanych narzędzi wsparcia przedsiębiorstw zaliczyć można instrumenty finansowe oraz niefinansowe. Polscy przedsiębiorcy mają dostęp do wsparcia dzięki różnego typu programom, które są zarządzane na szczeblach centralnym oraz regionalnym. Można do nich zaliczyć programy finansowane z funduszy strukturalnych UE, między innymi: dotacje, subwencje, dostępność do kredytów i pożyczek ${ }^{11}$.

7 K. Safin, Zarzadzanie małym i średnim przedsiębiorstwem, Wrocław 2008, s. 216.

8 A. Drab-Kurowska, A. Sokół, Małe i średnie przedsiębiorstwa wobec wyzwań rozwoju technologii XXI wieku, Warszawa 2010, s. 90-91.

9 D. Jegorow, Poglądy studentów ekonomii na wplyw członkostwa w Unii Europejskiej na polska gospodarke, [w:] Prawno-ekonomiczne szanse i bariery rozwoju przedsiębiorczości w Polsce i Europie, red. M. Stefański, Warszawa 2017, s. 10.

${ }^{10}$ M.W. Kozak, Między starym a nowym paradygmatem: wyzwania dla polskich regionów w latach 2014-2020, „Barometr Regionalny” 2015, nr 4 (13), s. 15-16.

11 W. Leoński, op. cit., s. 122. 
Interesujące badanie przeprowadził Łukasz Wściubak, który zajął się kwestią roli funduszy europejskich w funkcjonowaniu przedsiębiorstw. Z uzyskanych danych wynikało, że dotacje otrzymywane przez przedsiębiorstwa nie zawsze bezpośrednio odnosiły się do działalności innowacyjnej. W wielu przypadkach dofinansowanie przeznaczone było także na inwestycje w majątek trwały (na przykład budowę nowej hali produkcyjnej) czy też udział w targach zagranicznych ${ }^{12}$.

Uznać można, że zasadniczym celem oraz cechą europejskiej polityki spójności jest chęć zlikwidowania nierówności, które występują na poziomie życia grup społecznych w regionach europejskich. Politykę spójności należy traktować jako synonim polityki regionalnej oraz polityki strukturalnej. Główny cel tej polityki jest jeden - wyrównywanie nierówności na poziomie rozwoju regionów europejskich. Duża część nakładów środków unijnych na korygowanie struktury gospodarki adresowane jest do słabych gospodarczo regionów. Spójność społeczna sprowadza się do zmniejszenia zróżnicowań w wykorzystaniu zasobów ludzkich między określonymi regionami i zwiększeniu dostępu do pracy; uchodzi za warunek, a także wyraz solidarności społecznej ${ }^{13}$.

Jeśli ma się na uwadze podstawowe zasady wdrażania oraz wykorzystania środków z funduszy Wspólnoty, zostały one zachowane jako wytyczne działań. Oprócz tego pojawiło się także kilka innowacyjnych propozycji rozwiązań, które mają przyczynić się do usprawnienia polityki spójności.

Fundusze europejskie są jednym z ważniejszych źródeł pozyskiwania środków przez przedsiębiorstwa.

Aby zdobyć dofinansowanie z funduszy strukturalnych, niezbędne okazuje się spełnienie wielu wymogów oraz postępowanie według ściśle określonych procedur. Instytucją zarządzającą i decydującą o dystrybucji środków w ramach funduszy strukturalnych jest Komisja Europejska. Proponuje, a także określa ramy prawne funduszy, zabezpiecza środki, a następnie bierze udział w kontrolowaniu wydatkowania pieniędzy.

Wszelkie działania opierają się na zasadzie programowania, a to z kolei pozwala lepiej rozdysponować fundusze na inwestycje, a także zintegrować plany krajowe z perspektywami finansowymi Unii Europejskiej. Przy planowaniu zawsze wykorzystywane są perspektywy finansowe, które zarazem określają ramy czasowe. Państwa członkowskie muszą natomiast dopasować do nich swoje plany i tylko w takim zakresie negocjują warunki, na jakich są dla nich dostępne środki finansowe.

12 Ł. Wściubiak, Rola funduszy unijnych $w$ finansowaniu działalności innowacyjnej małych i średnich przedsiębiorstw wysokiej technologii w Polsce, „Acta Universitatis Lodziensis. Folia Oeconomica" 2014, nr 2, s. 302.

13 S. Pastuszka, Polityka Regionalna Unii Europejskiej - cele, narzędzia, efekty, Warszawa 2012, s. 100. 
Aby możliwe było efektywne wdrażanie i osiąganie zamierzonych celów, niezbędne jest sformułowanie mierzalnych i określonych w czasie działań, które określane są mianem projektu — bo to właśnie projekty są podstawą programowania regionalnego, a środki finansowe z funduszy strukturalnych mogą zostać wykorzystane wyłącznie poprzez liczne projekty opracowywane i realizowane przez sektor publiczny, pozarządowy czy też organizacje biznesowe. To z kolei oznacza ścisłą zależność między wyznaczonymi celami a jakością projektu. Postęp, który ma się dokonać przy wykorzystaniu środków unijnych, będzie tym większy i społecznie efektywny, im wyższa będzie jakość projektów przedstawianych do dofinansowania, a sama realizacja — zgodna z przyjętymi rezultatami.

W 1988 roku podczas wielkiej reformy został określony proces planowania, zarządzania, wdrażania oraz kontroli środków strukturalnych. Skuteczne programowanie działań na rzecz wspierania regionów stało się podstawowym celem działania. W treści tych zasad w sposób ogólny zaprezentowano podstawy wzajemnych stosunków pomiędzy państwami. Określono zasady finansowania, a przede wszystkim jak powinno się redystrybuować środki; kto może spodziewać się finansowania projektów z funduszy unijnych. Zasady oceny realizacji projektów początkowo opisywały rentowność, a następnie skuteczność projektów ${ }^{14}$.

Naczelną wartością była zasada solidarności - podstawa funkcjonowania całej UE i przesłanka pogłębiania integracji. Aby zrozumieć definicję solidarności, konieczne jest dokładne wyjaśnienie, czym ona jest - a mianowicie jest to taka zasada życia społecznego, która wspomaga działanie na rzecz wyrównywania nierówności socjalnych pomiędzy różnego typu grupami społecznymi; ma niwelować dysproporcje regionalne, sektorowe oraz strukturalne. Solidarność to wartości, ale i postawy, które przyczyniają się do zbliżania standardów życia poszczególnych grup ludności ${ }^{15}$. Zasada solidarności, w odniesieniu do polityki spójności, oznacza międzynarodową redystrybucję środków, która daje możliwość pokonania trudności gospodarczych.

Zasada partnerstwa w przypadku polityki regionalnej UE oznacza współpracę na każdym szczeblu — regionalnym, lokalnym oraz państwowym. Równość głosu, współodpowiedzialność za decyzje postrzega się jako podstawy realnego funkcjonowania tej zasady w UE.

Celem każdego kraju członkowskiego staje się pozyskanie środków z Funduszu Europejskiego, jako że są to środki, które dają możliwość rozwoju gospodarczo-społecznego: infrastruktury, rozwoju kapitału ludzkiego, wspierania innowacyjności oraz technologii. Pozyskanie środków okazuje się być trudne - zasada programowania opisuje, jaką drogę należy przejść, by otrzymać owe środki. Programowanie zasadniczo polega na tworzeniu stabilnego długoletniego planu

14 A. Bołdys, M. Rymarczuk, Polityka spójności Unii Europejskiej, Warszawa 2015, s. 12.

15 K. Głąbicka, M. Grewiński, Polityka spójności społeczno-gospodarczej Unii Europejskiej, Warszawa 2005, s. 71. 
rozwojowego, mającego gwarantować średnio- i długookresowy wzrost gospodarczy ${ }^{16}$.

Zapewnienie ścisłego powiązania pomiędzy polityką spójności a zarządzaniem gospodarką Unii ma pomóc zwiększyć efektywność wydatków, które są ponoszone z funduszy określonych we wspólnych ramach strategicznych poprzez wprowadzenie solidnych zasad gospodarczych. Fundusze te w razie potrzeby mogą zostać przekierowane na pomoc w rozwiązaniu problemów gospodarczych, z jakimi boryka się dany kraj. Komisja przedstawiła szereg istotnych zmian w sposobie kreowania i wdrażania polityki spójności, takich jak ${ }^{17}$ :

- większe skupienie się na priorytetach strategii Europa 2020, to znaczy na inteligentnym oraz zrównoważonym rozwoju sprzyjającym wzrostowi zatrudnienia;

— wspieraniu wysokiej wydajności;

- wspieraniu planowania zintegrowanego;

— skupianiu się na wynikach (monitorowanie postępów w osiąganiu uzgodnionych celów);

— wzmacnianie spójności terytorialnej;

— upraszczanie systemu udzielania pomocy.

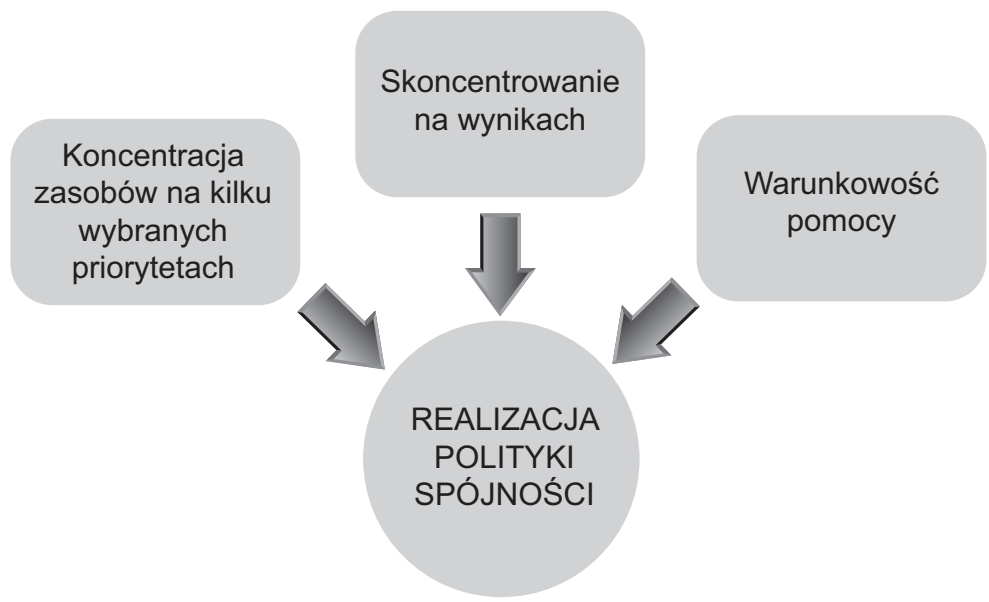

Rysunek 1. Zasady polityki spójności w nowym okresie programowania

Źródło: K. Borek, Znaczenie polityki spójności w zmniejszaniu różnic rozwojowych i strukturalnych między krajami Unii Europejskiej, Kraków 2015, s. 11.

Zasadniczy cel funkcjonowania funduszy strukturalnych to działania, które mają się przyczynić do zmniejszenia dysproporcji w rozwoju poszczególnych krajów. Obecnie do osiągnięcia tego celu wykorzystuje się dwa fundusze strukturalne:

16 A. Bołdys, M. Rymarczuk, op. cit., s. 14.

17 K. Borek, Znaczenie polityki spójności w zmniejszaniu różnic rozwojowych i strukturalnych między krajami Unii Europejskiej, Kraków 2015, s. 10. 
Europejski Fundusz Społeczny oraz Europejski Fundusz Rozwoju Regionalnego. Funkcjonuje również Fundusz Spójności, który podlega podobnym zasadom jak dwa wymienione. Różnicą pomiędzy tymi podstawowymi instrumentami polityki regionalnej jest to, że środki z tego funduszu nie są przyznawane danemu regionowi, ale przeznaczane na ogólnokrajowe programy ${ }^{18}$.

Celem, jaki stawia się przed EFS, jest wspieranie działań, które mają doprowadzić do poprawy jakości i dostępności miejsc pracy i możliwości zatrudnienia w UE. EFS został utworzony na podstawie postanowień traktatów rzymskich z 1957 roku. Fundusz ten kierowany jest do konkretnych grup społecznych, a nie do instytucji. EFS odpowiada za finansowanie tych obszarów, które wiążą się z realizacją polityki spójności UE. Wsparcie projektów realizujących cele EFS może wynosić maksymalnie $85 \%$. Pozostałe $15 \%$ ma pochodzić ze środków krajowych. Projekty, w których partycypuje finansowe EFS, mogą być realizowane zarówno przez instytucje, jak i podmioty prywatne.

Europejski Fundusz Rozwoju Regionalnego ustanowiono w 1975 roku i miał za zadanie zwalczanie skutków światowego kryzysu gospodarczego oraz tak zwanego „szoku naftowego" z 1972 roku. W ciągu lat rola tego funduszu wzrastała; był on ważnym narzędziem wyrównywania różnic rozwojowych pomiędzy państwami Unii. Fundusz ten ma na celu wspieranie endogenicznego rozwoju regionów przez wspieranie lokalnych inicjatyw rozwojowych, a także zachęcanie do rozwoju małych i średnich przedsiębiorstw ${ }^{19}$.

Fundusz Spójności, nazywany także Funduszem Kohezji, został ustanowiony na mocy zapisów Traktatu z Maastricht. Od 1994 roku konkretne państwa uzyskały wsparcie finansowe na redukowanie różnic w rozwoju gospodarczym i społecznym w stosunku do reszty państw członkowskich. W początkowym okresie istnienia tego narzędzia polityki regionalnej wsparciem finansowym objęte były Grecja, Hiszpania, Irlandia oraz Portugalia. Kolejne rozszerzenia UE w 2004 i 2007 roku sprawiły, że liczba państw objętych wsparciem z tego Funduszu została zwiększona. Warto zauważyć, że od 2006 roku obowiązują nowe regulacje odnośnie Funduszu Spójności ${ }^{20}$. Najważniejsza zmiana wiązała się ujednoliceniem zasad, które są stosowane wobec funduszy strukturalnych oraz Funduszu Spójności. W efekcie tego doszło do zwiększenia kompetencji decyzyjnych państw w stosunku do większości projektów, jednakże w dalszym ciągu Fundusz Spójności miał wspierać projekty i programy mające zasięg ogólnokrajowy. Za podstawowy cel Funduszu Spójności uznano dążenie do ułatwienia przygotowania do unii gospodarczej biedniejszych państw członkowskich przez wspieranie sektora środowiska i infrastruktury.

18 A. Tomaszewicz, Fundusze unijne a rozwój regionalny, [w:] Polityka gospodarcza jako gra w wyzwania i odpowiedzi rozwojowe, Warszawa 2014, nr 94, s. 219.

19 Ibidem.

20 J.W. Tkaczyński, M. Świstak, op. cit., s. 147. 
Projekty te miały w sposób istotny oddziaływać na rozwój sieci transportu transeuropejskiego, a także na poprawę ochrony środowiska. Fundusz ten ograniczono do państw, w których PKB na mieszkańca było niższe niż 90\% średniego PKB na mieszkańca Unii. Dodatkowo państwa musiały realizować taki program gospodarczy, który spełniałby wymogi konwergencji dotyczące długu publicznego, deficytu budżetowego, inflacji, stóp procentowych oraz kursu walutowego ${ }^{21}$.

\section{Wnioski i podsumowanie}

Fundusze są ściśle powiązane z polityką regionalną, polityką strukturalną i polityką spójności. Teoretycznie te pojęcia różnią się, w praktyce często są używane zamiennie.

Fundusze w przypadku zarządzania projektami są przede wszystkim ważnym źródłem finansowania projektów. Środki, które udostępnia instytucja zarządzająca, przeznacza się na dofinansowanie projektów, zgodnych z celami określonymi w poszczególnych programach operacyjnych. Dzięki środkom z UE firmy mogą podnosić między innymi jakość swoich produktów, zwiększać zatrudnienie, wdrażać innowacyjne rozwiązania czy przebranżawiać się.

Realizacja poszczególnych programów operacyjnych oparta została na zdefiniowanych oraz stosowanych schematach, które dokładnie wskazują następujące po sobie czynności, przyczyniające się do dofinansowania projektu, i niezbędne przepływy finansowe w ramach programu, jak na przykład Program Operacyjny Innowacyjna Gospodarka (POIG).

Projekty realizowane są na podstawie przepisów prawa unijnego (europejskiego), a więc rozporządzenia, na podstawie których Polska stała się dysponentem środków pochodzących z funduszy strukturalnych oraz prawa krajowego, na podstawie których realizuje się politykę rozwoju. Są to:

- ustawa z dnia 17 listopada 1964 roku Kodeks postępowania cywilnego, Dz.U. z 2015 r. poz. 2, 4, 218;

— ustawa z dnia 23 kwietnia 1964 roku Kodeks cywilny, Dz.U. z 2014 r. poz. $121 ;$

— ustawa z dnia 28 kwietnia 1936 roku Prawo wekslowe, Dz.U. z 2012 r. poz. 1529 ;

— ustawa z dnia 27 sierpnia 2009 roku o finansach publicznych, Dz.U. z 2015 r. poz. 238;

— rozporządzenie Ministra Rozwoju Regionalnego z dnia 14 lipca 2009 roku zmieniające rozporządzenie $\mathrm{w}$ sprawie wydatków związanych $\mathrm{z}$ realizacją programów operacyjnych;

- rozporządzenie Ministra rozwoju regionalnego z dnia 18 grudnia 2009 roku w sprawie warunków i trybu udzielania i rozliczania zaliczek oraz zakresu

21 A. Tomaszewicz, op. cit., s. 220. 
i terminów składania wniosków o płatność w ramach programów finansowanych z udziałem środków europejskich;

- ustawa z dnia 11 lipca 2014 roku o zasadach realizacji programów w zakresie polityki spójności finansowanych w perspektywie finansowej 2014-2020.

Z chwilą wstąpienia do UE w maju 2004 roku Polska zyskała możliwość korzystania z funduszy unijnych. Spośród państw, które przystąpiły do UE w 2004 roku, Polska uchodzi za zdecydowanie największego beneficjenta pomocy. Wiele polskich przedsiębiorstw stanęło przed szansą rozwoju oraz możliwością realizacji swoich projektów. Przedsięwzięcia te definiuje się jako projekty europejskie, które realizowane są w ramach określonego programu i mają służyć osiąganiu jego celów. Projekt taki jest przedmiotem umowy o dofinansowanie, której stronami są beneficjent oraz właściwa instytucja. Aby sprostać zadaniom oraz uzyskać założone rezultaty i produkty, przedsiębiorstwa powinny w sposób sprawny zarządzać swoimi projektami ${ }^{22}$.

\section{Bibliografia}

\section{Literatura}

Bołdys A., Rymarczuk M., Polityka spójności Unii Europejskiej, Warszawa 2015.

Borek K., Znaczenie polityki spójności w zmniejszaniu różnic rozwojowych i strukturalnych między krajami Unii Europejskiej, Kraków 2015.

Drab-Kurowska A., Sokół A., Małe i średnie przedsiębiorstwa wobec wyzwań rozwoju technologii XXI wieku, Warszawa 2010.

Florczak M., Parktina A., Zarządzanie projektem wspólfinansowanym ze środków unijnych w przedsiębiorstwie, „Zarządzanie i Finanse” 2012, nr 10.

Głąbicka K., Grewiński M., Polityka spójności społeczno-gospodarczej Unii Europejskiej, Warszawa 2005.

Jegorow D., Poglady studentów ekonomii na wpływ członkostwa w Unii Europejskiej na polska gospodarke, [w:] Prawno-ekonomiczne szanse i bariery rozwoju przedsiębiorczości w Polsce i Europie, red. M. Stefański, Warszawa 2017.

Kabalska A., Innowacje w kreowaniu i modyfikowaniu modeli biznesowych, [w:] Wybrane koncepcje zarzadzania w organizacjach, red. M. Smolarek, Sosnowiec 2016.

Klóska R., Innowacyjność polskiej gospodarki, „Studia Zarządzania i Finansów Wyższej Szkoły Bankowej w Poznaniu" 2015, nr 9.

Kozak M.W., Między starym a nowym paradygmatem: wyzwania dla polskich regionów w latach 2014-2020, „Barometr Regionalny” 2015, nr 4 (13).

Leoński W., Wpływ Unii Europejskiej na rozwój polskich przedsiębiorstw, „Handel Wewnętrzny” 2015, nr 3 .

Pastuszka S., Polityka Regionalna Unii Europejskiej - cele, narzędzia, efekty, Warszawa 2012.

Pomykalski A., Zarzadzanie innowacjami. Globalizacja, konkurencja, technologia informacyjna, Warszawa-Łódź 2001.

Safin K., Zarządzanie małym i średnim przedsiębiorstwem, Wrocław 2008.

22 M. Florczak, A. Parktina, Zarzadzanie projektem wspólfinansowanym ze środków unijnych w przedsiębiorstwie, „Zarządzanie i Finanse” 2012, nr 10, s. 215. 
Tomaszewicz A., Fundusze unijne a rozwój regionalny, [w:] Polityka gospodarcza jako gra w wyzwania i odpowiedzi rozwojowe, Warszawa 2014, nr 94.

Wściubiak Ł., Rola funduszy unijnych w finansowaniu działalności innowacyjnej małych $i$ średnich przedsiębiorstw wysokiej technologii w Polsce, „Acta Universitatis Lodziensis. Folia Oeconomica" 2014, nr 2.

\section{Inne}

Rozporządzenie Rady nr 1260 z dnia 21 czerwca 1999 roku, https://op.europa.eu/pl/publication-detail/-/publication/0495cad8-bda6-4b4f-852c-ce3dd3022392/language-pl.

Traktat o Unii Europejskiej, 7.02.1992, Maastricht, https://eur-lex.europa.eu/eli/treaty/teu_2012/oj. 